\title{
WHY ONLINE EDUCATION WILL ATTAIN FULL SCALE
}

\author{
John Sener \\ Sener Knowledge LLC \\ Director of Special Initiatives \\ The Sloan Consortium
}

\begin{abstract}
Online higher education has attained scale and is poised to take the next step in its growth. Although significant obstacles to a full scale adoption of online education remain, we will see full scale adoption of online higher education within the next five to ten years. Practically all higher education students will experience online education in some form during their collegiate career, and college students will be able to take online or blended degree programs and certificates in almost any subject. Full scale online education will occur as the result of compounded growth, increased familiarity and acceptance, various models of scalability, and possible wildcards which may accelerate growth. Online education will also attain full scale by becoming fully integrated into mainstream education. This transformation is necessary for online learning to reach its potential to improve the quality of education.
\end{abstract}

\section{KEYWORDS}

Online education, blended learning, scale

\section{INTRODUCTION}

At the 15th annual Sloan-C international conference in October 2009, the featured speaker Dr. A. Frank Mayadas called for his audience of online educators to embrace the opportunity and challenge of "moving online education to a truly large scale" [1]. His remarks reflected online education's transformation in recent years from a relative novelty to a significant force in higher education. From fall 2002 to fall 2009, online higher education enrollments in the United States rose from fewer than 10 percent of total enrollments (around 1.6 million learners) to almost 30 percent of total enrollments (around 5.6 million learners) [2]. Online higher education has attained scale and is poised to take the next step in its growth; indeed, Dr. Mayadas views the "scale-up" of online higher education as "the final frontier" in the process of attaining full "mainstream" status [3].

At the same time, a rising concern with online higher education's ability to scale has accompanied this rapid enrollment increase. Significant obstacles to a full scale adoption of online education remain, most notably level of faculty acceptance, financial issues, and various structural issues such as organizational structures or tenure and promotion policies. Online education is still not widely accepted at certain types of institutions, for instance at many of those where research and publication are higher priorities [2, 4, 5].

Will these obstacles retard the growth of online higher education before it can attain full scale adoption? Or will online higher education attain full scale despite these obstacles? This paper argues that the answer to the latter question is a resounding yes. Not only will we will see full scale adoption of online higher education, but it will happen within the next five to ten years. 


\section{WHAT IS “FULL SCALE" ONLINE EDUCATION?}

The definition of online education used here is simply the use of online technologies in formal higher education for teaching and learning. This definition includes not only courses, programs, and other learning experiences which are delivered exclusively via online means, but also the use of online technologies for teaching and learning in the entire spectrum of educational delivery, including blended and classroom courses. Thus, full scale online education will have the following characteristics:

1. The use of online technologies for teaching and learning will soon become a routine, commonplace, and integral part of the educational experience.

2. Practically all higher education students will experience online education in some form during their collegiate career. The experience will become as commonplace for them as owning a telephone in the U.S. (95 percent availability in 1990; around 98 percent from 2003-2008) [6, 7].

3. A majority of higher education students will take at least one online course during a given academic year.

4. A large majority of higher education students (70-80 percent) will take at least one online course during their collegiate careers.

5. Online courses will comprise a sizable proportion (20 percent or more) of the total credit hours in higher education.

Blended courses will comprise much of the remainder of the total credit hours in higher education.

College students will be able to take online or online/blended degree programs and certificates in almost any subject of their choosing at the associate, bachelor's, master's, and postgraduate certificate levels; that is, a full complement of online or online/blended degree programs will be available.

The realization of full scale online education has been informed by several different dimensions. The formulation closest to the Sloan Consortium, of course, is the one to which it owes its existence: the concept of Asynchronous Learning Networks (ALN) formulated by Dr. Mayadas at the Alfred P. Sloan Foundation. The ALN concept was based on "asynchronous interactivity" as distinct from previous distance education approaches such as self-study or interactive television, which offered limited possibilities for interaction. Instead, ALNs utilized the power of networks - not just electronic computer networks, but networks of people involved in the learning process - to create interactive communities which "provide learning to anyone who wishes to learn, at a time and place of the learner's choice" and not confined by the constraints of a classroom [8].

The metrics used to measure progress in adoption of ALN are reflected in the annual Sloan Survey of Online Learning, which measures the growth of online education in terms of the number and percentage of higher education students who have taken at least one online course during an academic year. The survey defines online courses as those in which 80 percent of instruction is delivered online [2,9]. (The annual survey data also provides an estimate of the number of institutions which offer online courses or programs, but these figures are typically not emphasized or cited.)

Online education will achieve full scale not just in terms of realizing the "ALN" vision of anywhere, anytime learning in online higher education, but also across the entire spectrum of education delivery:

Blended learning in higher education typically refers to courses and programs which combine online and classroom delivery modes. In practice, the distinction between online and blended is somewhat arbitrary, and different definitions are used. For example, the annual Sloan Survey of Online Learning defines a blended course as one in which 20-79 percent of the instruction is delivered online [2], while the Southern Association of Colleges and Universities sets the threshold for online and distance education courses at 50 percent [10], and the Commission for Higher Education uses the same 50 percent threshold for online education programs [11]. These contrasting definitions highlight the more important point: online 
Why Online Education Will Attain Full Scale

education delivery happens on a continuum which includes entirely online courses at one end, entirely 'face-to-face' courses at the other end, and a huge range of blended options in between.

Although Sloan-C issued a report on blended learning in 2007 [12], obtaining reasonably good estimates of blended learning adoption is extremely difficult. Much of the adoption of blended learning happens outside the purview of centralized administrative units or is otherwise not tracked for credit courses. For instance, it is quite easy for faculty to add discussions or other online assignments to classroom courses without detection [13, 14]. Nonetheless, the available information indicates that blended learning continues to grow. A few institutions which track both online and blended learning enrollments have found that blended learning has grown at their institutions over the past five years. At the University of Central Florida, blended learning registrations increased over 40 percent from 16,781 to 23,397 between the 2005-2006 and 2009-2010 academic years and have increased five-fold over the past nine years; UCF's blended courses have generated a 30 percent increase in student credit hours between fall 2009 and fall 2010 [15]. At the University of Illinois at Springfield, blended learning has steadily risen from 29 percent to 34 percent of all enrollments between the 2005-2006 and 2009-2010 academic years [16]; this represents an even larger overall growth since UIS's total enrollments have grown by about 15 percent during that period $[17,18]$.

The apparent growth in blended learning strongly suggests that the collegiate careers of practically all higher education students will soon be a blended learning experience. In some cases, the online portion of that learning experience will be in complete courses and even degree programs; in others, it will be in blended courses. Even students who do not take online or blended courses will still experience online education embedded into their classroom courses as a supplement to classroom learning-lessons, assignments, group projects, research projects, and other learning experiences for which online delivery will be used for the teaching and learning process. Within the broad higher education landscape, there will still be holdouts and pockets where purely online degree and certificate programs do not become widespread or ubiquitous - doctoral degree programs, elite liberal arts institutions, and many departments. Even in these locations, however, the use of online technologies will still have a presence-independent study and other specialty courses, research projects, other lessons and assignments. Essentially all higher education students will experience online education in some form during their collegiate career, thus making the use of online technologies for teaching and learning a routine, commonplace, and integral part of the educational experience - in other words, online education will attain full scale.

\section{HOW AND WHY FULL SCALE ONLINE EDUCATION WILL HAPPEN}

Online education will achieve full scale within the next five to ten years for several compelling reasons:

\section{A. The compounding effect: growth breeds growth}

U.S. online higher education continues to grow with no signs of letting up. It grew at an annualized rate of almost 20 percent from fall 2002-fall 2009, according to the annual Sloan Surveys of Online Learning [2], and there is no indication that its growth is about to taper off and plateau. If this trend continues, a majority of higher education students will take at least one online course by the 2013-2014 academic year. Even if future growth is cut in half to 9.7 percent per year (the lowest annual rate of increase since the first Sloan Survey in 2002), this benchmark will be reached by the 2017-2018 academic year-less than seven years from now.

This scenario is highly plausible because of several factors conducive to continued growth:

There are plenty of short-term and long-term pressures on higher education to grow, such as the current economic downturn, government and foundation initiatives to increase retention and graduation rates, and the growth in lifelong learning. Since online education has been growing for the past seven years at ten times the rate of higher education, it only makes sense that pressures to grow are most likely to support expanded adoption of online education, drawing more attention, energy, and resources to this area. For instance, three-quarters of academic leaders reported increased demand for online courses in fall 2009 due 
to the economic downturn [2], and the proportion of academic leaders who reported increased demand in fall 2008 was highest at those institutions which have the most online enrollments and the highest growth (public institutions and large institutions) [19].

Online education is higher education's chief engine of growth. The expansion in higher education in the last century was achieved by building extensive physical infrastructure (campuses, buildings, etc.) and hiring full-time faculty, both of which have become expensive, in many cases prohibitively so. Current funding patterns and competition pressures create disincentives against growth for a large proportion (estimated at 20 percent or more) of colleges and universities; instead, they simply become more selective with their applicant pool, and usually more expensive [20]. For-profit institutions are the only type of higher education institutions which have operated from a growth imperative and which have a growth rate comparable to online education [21]. Not surprisingly, much of the growth has happened in the form of online education; for example, in at least half of the 14 publicly traded for-profit institutions, which includes many of the largest ones, more than 50 percent of students are enrolled in exclusively online courses [22].

Online education enables higher education to scale rapidly while maintaining its broad array of offerings. Institutions have created large-scale online education programs where none existed previously by building on their existing strengths, such as faculty-led interactive instruction and well-established outreach and continuing education programs, and by developing new capacities such as replicable course development practices and pedagogy-focused faculty development [5]. Online education also enables higher education to scale relatively cheaply compared to other available options. By contrast, for-profit institutions know how to grow rapidly but not necessarily cheaply, as their tuition rates are far higher on average than those charged by public community colleges [20], and their array of program offerings and services provided are much more limited than non-profit higher education institutions [23].

The effects of compounding growth can already be seen in mature online programs which have reached full scale. For instance, over 55 percent of all students at the University of Illinois Springfield are taking an online course during the fall 2010 semester [18]. Annual online course registrations at the University of Central Florida have grown from fewer than 6,000 enrollments to 66,000 enrollments over the past ten years (1999-2000 to 2009-2010). Over the first five years of that period, UCF's online enrollment grew by about 23,500 students; over the last five years, it grew by over 37,300 students [24]. Colorado Community Colleges Online (CCCO) has grown from 109 enrollments (336 credit hours) in spring 1998 to 22,270 projected enrollments (73,000 credit hours) for the 2010-2011 academic year. Over the past two years, CCCO has grown at an annualized rate of 25 percent; as a result, about $80 \%$ of currently enrolled Colorado community college students have taken an online course [25]. The result is that many mature, larger enrollment online programs such as UIS, UCF, and CCCO are experiencing increased enrollment growth in numerical terms even when their growth rate has decreased, thanks to compounding growth and attaining large scale.

\section{B. The mainstreaming effect: familiarity breeds attempt}

Although there is considerable turnover in higher education as students graduate and new students enroll, there are several important effects resulting from more students taking more online courses:

- A higher percentage of students who are currently experiencing online courses

- More students who now have experience with taking online courses

- More students who are taking online courses who have previous experience taking them

- More students who know other students who have taken or are taking online courses

- More students who know other graduates who have completed online courses or programs

The net effect is that online education is now part of the U.S. collegiate experience. College students are aware of it even if they do not experience it directly. They may be dimly aware of it the way that liberal arts majors are dimly aware of the engineering building on their campus, but online education has become an accepted part of the landscape. 
Why Online Education Will Attain Full Scale

Familiarity is also important from the faculty perspective. The common belief that teaching or developing an online course requires more time and effort relative to a comparable face-to-face course is the most important barrier to teaching and developing online programs; quality and institutional support concerns are also important barriers. Once faculty have actual experience with developing or teaching an online course, however, these concerns tend to diminish, and online learning gains acceptance [26].

\section{The acceptance effect: a worthy alternative}

Acceptance extends not just to students and faculty but also to a sizable proportion of administrators, as evidenced by Sloan survey findings which indicate that online education is now an accepted part of the landscape in most sectors of higher education [2]. Online education has demonstrated its effectiveness, achieved actual and perceptual parity with traditional classroom-based education, and demonstrated its superiority to traditional education in many meaningful ways. A substantive body of research has demonstrated the effectiveness of online education [27, 28, 29, 30, 31]. From the Significant/No Significant Difference Phenomenon research [32, 33] to the early ALN Research studies [27] to more recent research and compilations of studies [30, 31, 34], a large body of research has provided strong evidence that online and blended learning are equal or superior to face-to-face instruction. Despite its limitations, the United States Department of Education study [35] seems to have had a strong effect on changing perceptions about online learning as indicated by its frequent citation as evidence that online and blended learning are equal or superior to face-to-face instruction $[36,37]$. In addition, online education offers ways to improve teaching and learning which traditional education delivery cannot match, such as improving student access and facilitating richer student discussions among many others $[28,38]$.

Blended learning has gained even more acceptance as a quality alternative which is often described as the "best of both worlds" [e.g., 39], a perception which was also reinforced by the USDE study findings [35]. Among other qualities, blended learning enables improved teaching and learning by implementing learner-centered pedagogies, enabling initiatives on an institutional scale, and increasing classroom utilization efficiency [24].

This combination - demonstrating parity and effectiveness, reducing the perception of inferior quality, and demonstrating superiority in meaningful ways - is a recipe for continued growth.

\section{The diversity effect: models and strategies for attaining scale}

\section{Established models for scalability}

The collective diversity of U.S. colleges and universities has long been regarded as one of its key strengths. Reflecting this diversity, online learning programs which have attained or are in the process of attaining full scale have done so in a variety of ways: for-profit mega-campuses such as the University of Phoenix; public mega-campuses such as the University of Maryland University College; statewide implementations such as the Illinois Online Network, Colorado Community Colleges Online, UMassOnline, and the State University of New York (SUNY) Learning Network; system wide implementations such as San Diego County Community College District; individual institutions such as the University of Central Florida's Distributed Learning Initiative, Thomas Edison State College's entirely online, multi-modal independent study programs, and the University of Illinois-Springfield "mirror campus"; and collaborations such as Western Governors University. Although there are a number of common factors which have contributed to the success of these institutions in attaining large scale [5], the variety of their models for attaining scale strongly suggests that higher education is successfully applying the strength of its institutional diversity to the online education arena.

Although institutions which are fully engaged with large, established online programs have accounted for the bulk of enrollment growth in online education [2], a number of other strategies are emerging which will also help compound growth, broaden familiarity, and increase acceptance of online and blended learning programs in new and perhaps influential ways. Three examples of these strategies are measured growth, supporting sustainability, and summer online programs. 


\section{Measured growth}

One emerging strategy for attaining scale is measured growth. Instead of large-scale implementations, numerous colleges and universities have established a significant presence of online and blended courses and programs at their institutions, for instance:

- Virginia Tech had around 22,000 for-credit distance education enrollments in its 2010 fiscal year, a $20 \%$ distance learning enrollment increase over the previous year; almost all of Virginia Tech's academic departments (96 percent) have engaged in distance learning over the past ten years, even though the total distance learning enrollments account for a relatively small proportion of total enrollment [40].

- Fort Hays State University has taken a relatively measured approach to developing its online learning program as part of its overall enrollment growth plan, actually restricting its growth by limiting resources devoted to its online programs in favor of its international programs [41]. Nonetheless, Fort Hays State's Virtual College program accounts for about one-third of total enrollment [42], and FHSU's president Ed Hammond projects that online learning enrollment will more than double at Fort Hays State University over the next ten years, accounting for over 40 percent of total enrollments by 2020 and accounting for more than 50 percent of the projected enrollment increase [41].

- Upper Iowa University is a nonprofit, non-denominational private institution in northeast Iowa, which started an online program in 1999 with 36 enrollments and had 2,200 students enrolled in its online programs during the 2009-2010 academic year. One-third of undergraduates and 70 percent of graduate students take one or more online courses during their UIU collegiate career [43].

\section{Supporting sustainability}

Concern about long-term sustainability has enabled online education to establish a presence at many institutions such as small arts liberal colleges, which historically have been averse to online learning. Many such institutions have used online education to support their long-term sustainability by expanding their reach and (in the case of some small colleges) by increasing enrollments, for example:

- Online education was a critical part of the strategic plan which Concordia University in Oregon developed in 2001 to ensure long-term sustainability by increasing its enrollment from 1,000 to 1,500 students over a ten-year period. Concordia exceeded its goal, serving a total of 1,900 students $(\sim 1,700$ FTE) in its 2010 fiscal year, in part by implementing undergraduate online courses and an online Master of Education degree with eight different concentrations. Concordia expects enrollments to increase significantly in the coming fiscal year to 300 or more graduate students, and it is currently developing a second online major with undergraduate and graduate degrees as a collaborative effort between its College of Education and College of Arts and Sciences. Concordia is tentatively projecting that the percentage of undergraduate credit hours delivered online will increase to 25 percent by 2020 , and it has also set a goal for 2020 that $100 \%$ of undergraduates will complete at least one course online. [44]

- Notre Dame College of Ohio views online education as sufficiently important to merit its own category in NDC's strategic plan. Online education has enabled NDC to increase enrollments and fulfill its mission to expand its reach to a valued target audience: single working mothers. NDC also sees online education as an important competitive advantage in a market with a very high concentration of small liberal arts colleges. Since its online education program started in 2006 with the conversion of offcampus teacher education licensure program courses to online courses, NDC's online course enrollment has grown consistently, currently accounting for about 30\% of NDC's enrolled credits [45]. NDC has developed other graduate online programs and 15 undergraduate general education courses, and several other fully online degree programs are in development. NDC's integration of the Moodle learning management system into all of its courses [46] has accelerated its adoption of blended learning [45].

- Upper Iowa University's online program has been fully self-supporting for the past five years, returning a surplus to the campus and helping ensure institutional long-term viability [5, 43].

\section{Summer online programs}


Why Online Education Will Attain Full Scale

Summer online programs provide another avenue for institutions which otherwise might resist online education to try out online education until it gains acceptance. For example, Emmanuel College started a summer online program in 2007 with seven courses; three years later, the college offers two online degree programs which are now offered year-round. Emmanuel's summer online program enrollment increased over 150 percent between summer 2007 and summer 2010, from 155 to 397 students; the summer online program helps Emmanuel student maintain the connection with the college community over the summer while allowing the college to retain tuition revenue which otherwise would flow to other institutions [47, 48]. Summer offerings have also been an important part of Notre Dame College of Ohio's online programs since its inception. All of its fully online programs include a summer session, generating increased summer enrollments which is crucial for enrollment-dependent schools such as NDC [46].

Although individually the enrollment numbers are not massive at small liberal arts colleges, a form of scale results from the cumulative presence of numerous institutions with online programs or a mix of online and blended courses among their offerings.

\section{E. The Wildcard effect: growth from unpredictable sources}

Some of the growth in online education has come from relatively predictable sources. For instance, community colleges have embraced online education, and community college enrollments have risen in past economic downturns, so it's not surprising that the most recent economic downturn has increased demand for online courses at community colleges [2]. But some sources of growth are essentially impossible to predict; for example, no one predicted the increase in online education enrollments as the result of the oil price shock of 2007-2008, during which the price of oil more than doubled from $\$ 62$ to $\$ 125$ per barrel [49]. From July through September 2008, University of Illinois Springfield professor Ray Schroeder's "Fueling Online Learning" blog chronicled how rising gas prices increased interest in online and blended learning. Summer enrollments in online courses surged at many institutions as commuting students sought ways to reduce the strain on their finances. Although it was next to impossible to determine how much of the increase in enrollment was directly attributable to high gas prices, Schroeder's blog contains numerous reports of booming summer online enrollments, with anecdotes from students who reported that high gas price was a major reason, often the sole reason for their enrollment [50].

Although by definition they are impossible to predict, two other candidates for "wildcards" which could cause a spike in the growth of online education are worth watching: 1) the current initiatives to improve retention and graduation rates, and 2) the potential need for an emergency response to a devastating natural or man-made hazard. The Obama Administration's American Graduation Initiative calls for an additional five million Americans to earn degrees and certificates from community colleges in the next decade [51]. This initiative is being complemented by foundation initiatives such as the Lumina Foundation's Goal 2025, which aims to increase the percentage of Americans with high-quality degrees and credentials to 60 percent by the year 2025 [52], and the Gates Foundation's Completion by Design program, which aims to help boost community college graduation rates [53]. Simple math indicates that attaining these ambitious targets will require extraordinary measures. Although these initiatives are likely to spur new approaches to delivering education, they are also likely to help spur the growth of online education as an established method for increasing higher education enrollments and thus an indispensible part of the overall strategy required to reach this goal.

If the effort to increase graduation rates is receiving lots of attention at the moment, the potential need for an emergency response to a devastating natural or man-made hazard is, by comparison, being overlooked. In 2005, the twin disasters of Hurricanes Katrina and Rita provided an example of how natural disasters could devastate educational delivery. The "Sloan Semester" was one initiative which helped mitigate the effect by providing free online courses to students impacted by the storm, but the experience demonstrated the need for higher education institutions to adopt strategies to prepare for future disasters [54]. Since then, although there have been relatively isolated episodes which have required individual institutions to respond to a natural or man-made disaster, there has been nothing on the scale of Hurricanes Katrina and Rita-yet. The H1N1 virus scare of 2009 turned out to be a false alarm in terms 
of its effects on higher education. Still, relatively few colleges and universities are prepared to maintain academic continuity when - not if - the next disaster strikes [55]. When it does, it is highly likely that online education will be an essential part of the solution.

A proactive response to this prospect would be to adopt a "bricks and clicks" strategy for educational delivery, in which every course and program offering is available through multiple delivery modalitiesonline as well as classroom. A few institutions have already adopted this strategy or are prepared to do so [e.g., 56]. More likely, this will happen as a reactive response-that is, it will take one (or perhaps more) devastating disasters to persuade higher education institutions to adopt this strategy, perhaps after seeing one or more institutions cease to exist as the result of failing to recover from a disaster. If they do, however, the inevitable outcome will be another large spike in the adoption of online education.

\section{CLOUDS ON THE HORIZON?}

Despite the compelling evidence that online education's growth will continue and that there are no specific signs of a slowdown, many observers see some "clouds on the horizon" [57] which might result in sluggish future growth or even a downturn in enrollments:

The current economic slowdown is accelerating demand, so online learning growth will taper off when the economy eventually improves $[2,57]$;

Budget pressures in the large public institutions which are fueling most of the enrollment growth will ultimately hamper further growth due to lack of available resources to meet demand $[2,57,58,59]$;

New federal rules on financial aid and student recruiting may negatively impact enrollments [2, 57];

Online education's reputation, and thus its growth, is under threat of contamination by its close association with for-profit higher education whose reputation is currently under close scrutiny; an

A shortage of trained faculty will slow down the ability to meet demand and possibly also drive up hiring costs.

None of these factors can be dismissed out of hand; indeed, one or more of them might also become a wildcard which slows the juggernaut of online learning growth or even stop it altogether. However, such a scenario is unlikely for several reasons:

- It is unclear that the economic slowdown is in fact accelerating demand. Sloan survey report statistics indicate that online enrollment growth grew at a high rate when the economy was relatively strong (over 20 percent annually from fall 2002 to fall 2006) [2]. Even if the economic slowdown is accelerating demand, it is more likely that online enrollment growth will return to "historic" levels when economic conditions recover. Even historically low growth levels (i.e., the 9.7 percent growth rate reported between fall 2005 and fall 2006) will yield a majority of higher education students taking online courses within seven years.

- The argument that budget pressures will hamper rather than fuel online learning growth seem to be based on lack of infrastructure [58] which leads to lack of capacity to meet student demand [59]. However, it is unclear that "student demand" is an actual driver in the online education context any more than it is in the rest of higher education. Concerns about lack of infrastructure may also indicate that online education could grow even faster than it has been if the infrastructure were in place. The arguments that budget pressures will fuel rather than hamper online learning growth [e.g., 58, 60] are at least as plausible.

- Online enrollment growth has been particularly strong at for-profit institutions, which reportedly comprise 27 percent of all online enrollments in higher education [58]. However, given that the bulk of enrollment growth is happening at two-year and large public institutions [2], a slowdown or even decline in for-profit online enrollments would not be large enough to slow the growth rate down completely or even considerably. The reported slower growth rates of larger, fully engaged institutions [2] can be deceptive; as the UIS, UCF, and CCCO examples show, institutions with large enrollments 
experience larger numerical increases even as their internal growth rates slow, and these large increases contribute disproportionately to the total increase in online learners nationwide.

- To the extent that "reputation contamination" is an actual threat, it is one of perception similar to the one which online higher education faced in the early years of its existence. The battle of public perception can be won just as it has been within most sectors of higher education.

- Faculty at all levels of experience are about equally likely to teach online [26], thus faculty who will teach online in the future are just as likely to come from the existing ranks-faculty who have taught online previously, or who want to increase their online faculty workload, or who want to try it because their colleagues have-as they are from a pool of adjunct faculty. Preparing faculty to learn how to teach online is a serious professional development challenge, but most institutions with large online enrollments have created their own internal faculty preparation programs, Other available offerings such as the Sloan-C Certificate program are also helping to meet the demand for preparing faculty to teach online.

- Many of the frequently cited barriers such as perceived quality or faculty concerns about level of effort and support have been reported consistently for years, and online learning growth has proceeded nonetheless. Why should the future be any different?

- The target metric being used (number of higher education students who enroll in online courses) is not near its saturation level relative to the current penetration rate of 30 percent. Growth rates will naturally slow as the maximum is neared, but the potential unreached audience remains huge.

The far more likely scenario is that the pressures and incentives to grow far outweigh the obstacles to growth and will overcome them. Online and blended education provide long-term opportunities for higher education to grow, enabling institutions to expand student markets beyond traditional local, regional and state markets into the national and international realm [60].

\section{THE DISAPPEARANCE OF DELIVERY MODE}

Intriguingly and ironically, online education will also attain full scale by disappearing into the background as it becomes fully integrated and thus essentially indistinguishable from mainstream education. This will happen for several reasons.

First, the proliferation of blended learning is blurring the distinction between online and classroom education through its wide range of course design possibilities which utilize both delivery modalities. Good blended learning course design focuses on using each modality for its maximum benefit, but the resulting courses are increasingly difficult to characterize by delivery mode since they integrate online and classroom education in an ever expanding variety of ways. Many classroom courses use online technologies for purposes other than teaching and learning such as access to learning resources, communication of information, and learning management, further blurring the distinction.

Second, emerging online technologies are getting ever easier to integrate with classroom-based learning. In the early days of online education, it was customary to think of the technologies used (online discussion software, learning management systems, assessment software, etc.) primarily in terms of delivery mode, that is, as online technologies distinct from those used in classroom-based education. Increasingly, however, technologies are known and used primarily for their affordances rather than by their delivery mode. One example is student creation of wiki textbooks: students use an online technology (wikis) to create content for textbooks in classroom courses by working online or in person; other online technologies such as specialized software for writing wiki textbooks also facilitate other aspects of the process such as assessment and peer review $[61,62,63]$. Podcasting enables students to listen to recorded lectures or other content, and to (co-)create content for course assignments, review sessions, or other purposes [64]. Another example which has become a well-established practice is the application of learning resources developed for online courses to classroom courses. Once an unanticipated benefit, online education resources are now being intentionally developed for use in multiple modalities, as online resources such as the OER Commons illustrate [65]. 
Mobility makes "online education" a moving target. Users can listen to podcasts online using a desktop computer or mobile device with wireless access - or they can download the podcasts on to a mobile device and listen to it anywhere. Emerging practices in mobile learning ("mLearning") also blur the distinction between "online" and other forms of education. For instance, the California State University, Monterey Bay's Wireless Education and Technology Center (WeTEC) web site describes a variety of diverse mLearning projects where "educators conduct wireless interactive webconferences with local K12 and high school classrooms and teachers by sharing images and data," conduct field archaeology with Internet connectivity to a classroom via a satellite dish, and do field geology using GPS \& GIS (Geographic Information Systems)-equipped Tablet PCs as digital field notebooks [66].

Online education is also going offline. Emerging "portable cloud computing" initiatives such as Thomas Edison State College's FlashTrack project are making it much easier for students and instructors to work offline. This initiative enables on-the-go students to keep up with their online studies using a variety of mobile devices, including laptops, Netbooks, gaming devices, and mobile phones. Entire courses can be stored on an inexpensive USB flash drive which contains content, productivity applications, and even a basic course management system. The course is essentially self-contained; no installation onto a computer is necessary, and nothing is left on the computer or other device after it is used, which eases security concerns. Instead of being tethered to a computer, students can do their work offline, only going online to send assignments or receive updates [67,68]. Given the continuing trend toward ever greater storage capacity in ever smaller devices as exemplified by currently available USB flash drives and wrist bands with considerable storage capacities (2-16GB) at low cost (\$15-50), it may soon become necessary to start talking about "offline education."

The distinction between online and classroom education is also blurred by introducing the element of choice, as exemplified by courses where students choose the delivery mode. Early examples included Ohio State University's "buffet" style calculus course [69], which allowed students to select a delivery mode at the beginning of the course, and Virginia Tech's Math Emporium, where students can choose whether to do assignments online in a computer lab, access the course materials from their dorm computers, receive 'on-the-spot' one-on-one tutoring, or attend a small group tutoring session [70]. A more recent example is San Francisco State University's "HyFlex" (hybrid + flexibility) course design, which enables students to choose between online and in-class participation modes [71]. In effect, each student creates his own individualized delivery mode mix in such courses; increasingly, "online," "blended," or "classroom" describe choices rather than courses.

\section{WHY FULL SCALE ONLINE EDUCATION IS IMPORTANT}

Online learning has taken hold in higher education because it improves access for all learners and provides new access for previously underserved learners. Online education will continue to be wellsuited to fulfill these roles, and the need and demand for education is likely to continue to grow. Thus full scale online education is important because it represents the realization of the dream to provide greater educational access.

Blended learning, and the integration of online learning into mainstream education, both enable online technologies to be effectively used for teaching and learning in ways that previously were impossible. If the first era in the history of online education was focused on providing access, the second era has the potential to be defined by improving quality, and stakeholders are turning their attention to this area [72]. Full scale online education is also vitally important not just to address current concerns about its perceived quality, but also as a means for improving the quality of all education in the foreseeable future.

\section{ACKNOWLEDGEMENTS}

The author thanks Janet Moore for her insightful comments on an earlier draft of this manuscript, and also thanks the many colleagues referenced in this article for their invaluable contributions.

\section{ABOUT THE AUTHOR:}


John Sener is the founder/CLO of Sener Knowledge LLC, a consulting practice focused on supporting quality in technology-enabled education through knowledge development and dissemination, evaluation, strategic planning, and learning design. As Director of Special Initiatives for the Sloan Consortium, he is also involved in a wide variety of Sloan-C activities. His career in education and training over the past 30 years is a unique mixture of broad practical experience and academic expertise. He holds a M.S. degree in Education from Johns Hopkins University and a B.A. in Psychology from Oberlin College.

\section{REFERENCES}

1. Mayadas, A.F., Opening Remarks. The Fifteenth Annual Sloan-C International Conference on Online Learning: The Power of Online Learning: Opportunities for Tomorrow, Orlando, FL, October 28, 2009.

2. Allen, I. E. and Seaman, J., Class Differences: Online Education in the United States, 2010. Babson Survey Research Group, November 2010. http://sloanconsortium.org/sites/default/files/class_differences.pdf.

3. Mayadas, A. F., Personal communication, August 2010.

4. Parry, M., Online Education, Growing Fast, Eyes the Truly 'Big Time'. Chronicle of Higher Education, October 30, 2009. http://www.webcitation.org/515WPEblH.

5. Moloney, J., and Oakley, B. II., Scaling Online Education: Increasing Access to Online Education. Journal of Asynchronous Learning Networks, 10(3), July 2006.

6. Bureau of the Census, We Asked...You Told Us: Telephone and Vehicle Availability. Census Questionnaire Content, 1990 CQC-26. http://www.census.gov/apsd/cqc/cqc26.pdf.

7. Blumberg, S.J., and Luke, J. V., Wireless Substitution: Early Release of Estimates From the National Health Interview Survey, July-December 2009. Centers for Disease Control, Division of Health Interview Statistics, National Center for Health Statistics. http://www.cdc.gov/nchs/data/nhis/earlyrelease/wireless201005.pdf.

8. Mayadas, A. F., Asynchronous Learning Networks: A Sloan Foundation Perspective. Journal of Asynchronous Learning Networks, 1(1), March 1997.

9. Allen, I. E. and Seaman, J., Sizing the Opportunity: The Quality and Extent of Online Education in the United States, 2002 and 2003. Sloan-C, September 2003. http://sloanconsortium.org/sites/default/files/sizing opportunity 2.pdf.

10. Southern Association of Colleges and Universities, Distance and Correspondence Education: Policy Statement, June 2010.

11. Commission for Higher Education, Policy for Delivering Degree Programs through Distance Technology, March 13, 1998. http://www.in.gov/che/files/9803029B.pdf. http://www.sacscoc.org/pdf/Distance\%20and\%20correspondence\%20policy\%20final.pdf.

12. Allen, I. E., Seaman, J., and Garrett, R., Blending In: The Extent and Promise of Blended Education in the United States. Sloan-C, March 2007. http://sloanconsortium.org/sites/default/files/Blending_In.pdf.

13. Turoff, M., Personal communication, September 27, 2010.

14. Zotti, R., Personal communication, October 5, 2010.

15. Hartman, J., Personal communication, September 26, 2010.

16. Swan, K., Personal communication, September 26, 2010.

17. University of Wisconsin, Select Public University President/Chancellor Salaries and Institution Enrollment. http://www.wisconsin.edu/news/2006/06-2006/jun09 chanc-pres-salaries-WI-IAIL-MN.pdf.

18. University of Illinois Springfield, UIS sets a record with 5,174 students enrolled. News@ Illinois Springfield. http://news.uis.edu/2010/09/uis-sets-record-with-5174-students.html.

19. Allen, I. E. and Seaman, J., Learning on Demand: Online Education in the United States, 2009. Babson Survey Research Group, January 2010. http://sloanconsortium.org/publications/survey/pdf/learningondemand.pdf. 
20. Kamenetz, A., DIY U: Edupunks, Edupreneurs, and the Coming Transformation of Higher Education. White River Junction, VT: Chelsea Green, 2010, pp. 54-72.

21. Bennett, D.L., Lucchesi, A.R., and Vedder, R.K., For-Profit Higher Education: Growth, Regulation, and Innovation, p. 10. http://www.centerforcollegeaffordability.org/uploads/ForProfit_HigherEd.pdf.

22. United States Senate, Emerging Risk?: An Overview of Growth, Spending, Student Debt and Unanswered Questions in For-Profit Higher Education. United States Senate Health, Labor, Education, and Pensions Committee, Tom Harkin, Chairman, June 24, 2010. http://harkin.senate.gov/documents/pdf/4c23515814dca.pdf.

23. Klor de Alva, J., For Profit Colleges and Universities: America's Least Costly and Most Efficient System of Higher Education: Case Study-University of Phoenix. Nexus Research Institute, August 2010. This report argues that for-profit institutions are more cost-effective for taxpayers, but the argument was based on several questionable assumptions, including counting public and private non-profit investment, endowment, and other income as "forgone taxes," and obscuring the fact that various funding sources pay for an entire array of programs and services at higher education institutions which are not offered by for-profit institutions.

24. Hartman, J., The Promise and Practice of Blended Learning. Sloan-C Blended Learning Conference, Chicago, April 19, 2010.

http://sloanconsortium.org/sites/default/files/webform/2010bldPresentations/hartman sloanc Ble nded.pdf.

25. Cheney-Steen, L., Personal communications, September 29 \& October 5, 2010.

26. Seaman, J. Online Learning as a Strategic Asset, Volume II: The Paradox of Faculty Voices: Views and Experiences with Online Learning. American Public and Land-Grant Universities, August 2009. http://sloanconsortium.org/sites/default/files/APLU_online_strategic_asset_vol21.pdf.

27. Hiltz, S. R., Y. Zhang, and M. Turoff, Studies of effectiveness of learning networks. P. 15-41 in Elements of Quality Online Education: Learning Effectiveness, Cost Effectiveness, Access, Faculty Satisfaction, Student Satisfaction, J. Bourne \& J. C. Moore (Eds.). Needham, MA: Sloan Center for Online Education, 2002.

28. Kassop, M., Ten Ways Online Education Matches, or Surpasses, Face-to-Face Learning. The Technology Source, May/June 2003.

http://technologysource.org/article/ten_ways_online_education_matches_or_surpasses_facetoface learning/.

29. Swan, K., Learning Effectiveness: What the Research Tells Us. Elements of Quality Online Education: Practice and Direction, J. Bourne \& J. C. Moore (Eds.). Needham, MA: Sloan Center for Online Education, 2003, pp 13-45.

30. National Survey of Student Engagement, Promoting Engagement for All Students: The Imperative to Look Within. 2008 Results.

http://nsse.iub.edu/NSSE 2008 Results/docs/withhold/NSSE2008_Results_revised_11-142008.pdf.

31. National Survey of Student Engagement, Assessment for Improvement: Tracking Student Engagement Over Time. Annual Results 2009. http://nsse.iub.edu/NSSE 2009 Results/pdf/NSSE AR 2009.pdf.

32. WCET, No Significant Difference Phenonemon web site. www.nosignificantdifference.org.

33. Russell, T., The No Significant Difference Phenomenon: A Comparative Research Annotated Bibliography on Technology for Distance Education. IDECC, Montgomery, AL, 2001.

34. Cook, D., Levinson, A., Garside, S., \& Dupras, D., Internet-based learning in the health professions: A meta-analysis. JAMA, 2008;300(10):1181-1196 (doi:10.1001/jama.300.10.1181). http://jama.ama-assn.org/cgi/content/full/300/10/1181.

35. United States Department of Education, Evaluation of evidence-based practices in online learning: A meta-analysis and review of online learning studies. U.S. Department of Education, 
Office of Planning, Evaluation, and Policy Development, Washington, DC. 2009. http://www2.ed.gov/rschstat/eval/tech/evidence-based-practices/finalreport.pdf.

36. Christian Science Monitor, Virtual ivy: why the US needs more e-colleges editorial, August 31, 2009. http://www.csmonitor.com/Commentary/the-monitors-view/2009/0831/p08s01comv.html.

37. Vien, C., The New Gold Standard? Online Learners Outperform On-site students. UOPX Knowledge Network, January 13, 2010. http://www.phoenix.edu/uopx-knowledgenetwork/articles/current-conversations/online-learners-outperform-on-site-students.html.

38. Allen, I. E. and Seaman, J., Online Nation: Five Years of Growth in Online Learning. Sloan-C, October 2007. http://sloanconsortium.org/sites/default/files/online nation.pdf.

39. Harding, A., Kaczynski, D., \& Wood, L., Evaluation of blended learning: Analysis of qualitative data. Proceedings of the Blended Learning in Science, Teaching and Learning Symposium, University of Sydney, Australia, September 30, 2005.

40. Halsey, M. Personal communications, September 29 and October 27, 2010.

41. Hammond, E.H., Presidents and CEO's Opportunities \& Challenges: Leadership Under New Norms. NUTN Summit, Colorado Springs, CO, September 28, 2010.

42. FHSU News, FHSU sets another enrollment record. FHSU News, September 23, 2010. http://www.fhsu.edu/news/Enrollment-record/.

43. Chown, P., Personal communication, October 1, 2010.

44. Driessner, J. Personal communication, October 4, 2010.

45. Davis, R. Personal communication, September 27, 2010.

46. Notre Dame College, Online Learning Resources web site. http://www.notredamecollege.edu/academics/online-learning/online-learning-resources.

47. Neamtu, R., Crossroads of the digital and real worlds: virtual field trips for online and blended courses. Third Annual Emerging Technologies for Online Learning Symposium, San Jose, CA, July 2010.

http://hosted.mediasite.com/mediasite/SilverlightPlayer/Default.aspx?peid=78c5623b4e9246e8b6 cf307efe9b4ad91d.

48. Neamtu, R., Personal communication, October 4, 2010.

49. FedPrimeRate.com, Crude Oil Price History. http://www.nyse.tv/crude-oil-price-history.htm.

50. Schroeder, R., Fueling Online Learning blog. http://fuelingonline.blogspot.com.

51. The White House Office of Social Innovation and Civic Participation, Investing in Education: The American Graduation Initiative. July 14, 2009. http://www.whitehouse.gov/blog/Investingin-Education-The-American-Graduation-Initiative/.

52. Lumina Foundation, Goal 2025. http://luminafoundation.org/goal 2025/.

53. Bill and Melinda Gates Foundation, Foundation Launches $\$ 35$ Million Program to Help Boost Community College Graduation Rates, October 4, 2010. http://www.gatesfoundation.org/pressreleases/Pages/increasing-community-college-graduation-rates-101004.aspx.

54. Sloan Consortium, The Sloan Semester. http://sloanconsortium.org/sloansemester.

55. Kelderman, E., Most Colleges Avoid Risk Management, Report Says. Chronicle of Higher Education, June 25, 2009. http://chronicle.com/article/Most-Colleges-Avoid-Risk/47806.

56. University of Maryland University College, UMUC Classroom Interruption Planning Guide for managing unplanned classroom closings, August 8, 2008. http://www.umuc.edu/interruptionguide/planninguide.pdf.

57. Babson Survey Research Group, Online Education Grows by Almost a Million Students. http://www3.babson.edu/ESHIP/research-publications/survey-research-group.cfm.

58. Kolowich, S. Speeding Toward a Slowdown? Inside Higher Ed, November 16, 2010. http://www.insidehighered.com/news/2010/11/16/survey. 
59. Kolowich, S. Internal Barriers to Online Expansion. Inside Higher Ed, November 12, 2010. http://www.insidehighered.com/news/2010/11/12/online.

60. Betts, K., Hartman, K., \& Oxholm, C. Re-examining \& repositioning higher education: 20 economic and demographic factors driving online and blended program enrollments. Journal of Asynchronous Learning Networks 13(4), December 2009.

61. Havenstein, H., Wiki becomes textbook in Boston College classroom. Computerworld, August $15,2007$.

62. Gehringer, E. F., Ehresman, L. M., Conger, S. G., and Wagle, P. A., Reusable learning objects through peer review: The Expertiza approach. Innovate-Journal of Online Education 3:6, August/September 2007.

63. Kidd, J. J., O'Shea, P. M., Kaufman J., Baker, P. B., Xiao, Y., \& Allen D. W., Traditional Textbook vs. Student-authored Wikibook: A Quasi-Experimental Study of Student Attitudes and Behaviors. Paper presented at annual meeting of American Educational Research Association, San Diego, CA, April 2009.

64. Miller, D., Podcasting at the University of Connecticut: Enhancing the Educational Experience. Campus Technology, October 18, 2006. http://campustechnology.com/articles/2006/10/podcasting-at-the-university-of-connecticutenhancing-the-educational-experience.aspx.

65. ISKME, OER Commons: Open Educational Resources. http://www.oercommons.org/.

66. California State University Monterey Bay, Wireless Education and Technology Center web site. http://wetec.csumb.edu/site/x17155.xml.

67. van Zyl, H., Portable Cloud Computing: A Case Study and a Report. LearnCon, San Diego, June 16, 2010. Summary: http://www.elearningguild.com/mLearnCon/concurrentsessions/session-details.cfm?event $=62 \&$ date $=06 / 16 / 2010 \# 2467$.

68. Cooper, M., Breaking Free of the Technology Bungy: Delivering Untethered Learning for Today's Socially Wired World. NUTN Summit, Colorado Springs, CO, September 29, 2010.

69. Jarmon, C. G. (ed.), Pew Project Updates: Round III, Ohio State University: Statistics. The Pew Learning and Technology Program Newsletter, 4 (3), September 2002. http://www.thencat.org/PCR/PewNews/PLTP13.html.

70. Virginia Polytechnic Institute and State University, Virginia Tech Math Emporium home page. http://www.emporium.vt.edu/.

71. Beatty, B. Using the "HyFlex" Course and Design Process. http://sloanconsortium.org/effective practices/using-quothyflexquot-course-and-design-process

72. Parry, M., How the Gates Foundation Will Spend Its Educational Technology Dollars. Chronicle of Higher Education, October 1, 2010. http://chronicle.com/blogPost/How-the-GatesFoundation-Will/27362/?sid=wc\&utm_source=wc\&utm_medium=en. 